\title{
Peluang dan Tantangan Pengembangan Souvenir Desa Wisata Berbasis Kerajinan Lokal
}

\author{
Gusti Ngurah Adi Wiriatama*1, Nyoman Dini Andiani ${ }^{2}$ \\ Universitas Pendidikan Ganesha, Indonesia ${ }^{1,2}$ \\ Email: ngurahwiria07@gmail.com
}

\begin{abstract}
Tigawasa Village is one of the Old Villages or Bali Aga villages in Banjar District, Buleleng Regency, Bali which is the center of bamboo handicrafts. The local handicraft really needs development, one of the developments of the local handicrafts of Tigawasa Village, namely tourism village souvenir products. The development of local handicraft-based tourism village souvenirs is the beginning of increasing the value of local crafts in Tigawasa Village. This article describes the opportunities and challenges of developing local handicraft-based tourist village souvenirs in Tigawasa Village, which is the center of bamboo handicrafts in the Bali Aga village environment, Buleleng, Bali. The method used is a descriptive qualitative method which begins with data collection from interviews with several informants, filling out questionnaires by tourists visiting Tigawasa Village and also direct documentation to Tigawasa Village such as traditional houses and also to craftsmen in Tigawasa Village. The results show that local crafts have the opportunity to develop as souvenirs because the crafts produced are of good quality, besides that the tourism development component is also an opportunity in the development of these souvenirs such as tourists visiting Tigawasa Village will be invited to do weaving activities (something to do) with the woven results can be used as a souvenir to take home (something to buy). The results of the questionnaire also stated that $70 \%$ of tourists strongly agree with the existence of local handicraft-based tourism village souvenirs, and $30 \%$ agree and there are no opinions disagree and strongly disagree. The challenges faced related to the development of tourism village souvenirs include the limitations of existing bamboo sources so that craftsmen buy materials from outside the village so that additional capital is needed so that capital is also a challenge for Tigawasa Village crafts, lack of innovation from bamboo crafts, and lack of promotion. With the development of local handicraft-based souvenirs in Tigawasa Village can increase the selling value of local crafts, can make it a tourist attraction and as a memory for every tourist who comes to Tigawasa Tourism Village.
\end{abstract}

Keywords: Opportunities and Challenges, Souvenir Development, Local Handicraft, Tigawasa Village.

\begin{abstract}
Abstrak
Desa Tigawasa adalah salah satu Desa Tua atau desa Bali Aga yang ada di Kecamatan Banjar, Kabupaten Buleleng, Bali yang menjadi sentral kerajinan bambu. Kerajinan lokal tersebut sangat perlu adanya pengembangan, salah satu pengembangan dari kerajinan lokal Desa Tigawasa yaitu produk souvenir desa wisata. Pengembangan souvenir desa wisata berbasis kerajinan lokal menjadi awal peningkatan nilai kerajinan lokal di Desa Tigawasa. Artikel ini memaparkan tentang peluang dan tantangan pengembangan souvenir desa wisata berbasis kerajinan lokal di Desa Tigawasa yang menjadi sentral kerajinan bambu di lingkungan desa Bali Aga, Buleleng, Bali. Metode yang digunakan berupa deskriptif kualitatif yang diawali dengan pengumpulan data dari wawancara terhadap beberapa narasumber, pengisian kuisioner oleh wisatawan yang berkunjung ke Desa Tigawasa dan juga dokumentasi langung ke Desa Tigawasa seperti ke rumah adat dan juga ke pengrajin di Desa Tigawasa. Hasil penelitian menunjukan kerajinan lokal berpeluang dalam pengembangan sebagai souvenir dikarenakan kerajinan yang dihasilkan memiliki kualitas yang bagus selain itu komponen pengembangan wisata juga menjadi peluang dalam pengembangan souvenir ini seperti para wisatawan yang berkunjung ke Desa Tigawasa akan diajak untuk melakukan kegiatan menganyam (something to do) dengan hasil anyaman tersebut bisa dijadikan sebagai souvenir untuk dibawa pulang (something to buy). Hasil kuisioner juga menyatakan $70 \%$ wisatawan sangat setuju dengan adanya souvenir desa wisata berbasis kerajinan lokal, dan $30 \%$ menyatakan setuju dan tidak adanya pendapat tidak setuju dan sangat tidak setuju. Tantangan yang dihadapi terkait pengembangan souvenir desa wisata meliputi keterbatasan sumber bambu yang ada sehingga pengrajin membeli bahan dari luar desa dengan begitu perlunya modal tambahan sehingga modal juga menjadi
\end{abstract}

* Corresponding author

Received: July 02, 2021; Revised: July 27, 2021; Accepted: July 29, 2021 
tantangan bagi kerajianan Desa Tigawasa, kurangnya inovasi dari kerajinan bambu, serta promosi yang masih kurang. Dengan pengembangan souvenir berbasis kerajinan lokal di Desa Tigawasa dapat meningkatkan nilai jual kerajinan lokal, dapat menjadikan daya tarik wisatawan dan sebagai kenangan bagi setiap wisatawan yang datang ke Desa Wisata Tigawasa.

Kata Kunci: Peluang dan Tantangan, Pengembangan Souvenir, Kerajinan Lokal, Desa Tigawasa.

\section{A. PENDAHULUAN}

Buleleng adalah salah satu kabupaten di Bali yang letaknya sebelah utara pulau Bali. Buleleng memiliki potensi wisata yang cukup menjanjikan dilihat dari lokasinya yang nyegara gunung yaitu terdapat pegunungan serta ditambah dengan perairan atau pantainya. Lokasi tersebut yang menyebabkan Buleleng banyak sekali memiliki destinasi wisata yang mampu menarik wisatawan untuk datang ke Kabupaten Buleleng. Kabupaten yang luasnya 1.356,88 km² ini juga ditetapkan memiliki 31 desa wisata yang dapat dikunjungi oleh wisatawan yang ingin menikmati wisata pedesaan dengan keindahan alam serta budayanya. Salah satu desa wisata yang sekarang ini telah berkembang menjadi destinasi wisata yaitu desa Bali Aga.

Bali Aga adalah desa tua yang penduduknya memang Bali asli yang memiliki kebudayaan yang masih diwariskan dari leluhur hingga sekarang. Bagian dari desa Bali Aga di Buleleng ini yaitu berada di Kecamatan Banjar yang sering dikenal dengan singkatan SCTPB ( Sidatapa, Cempaga, Tigawasa, Pedawa, dan Banyusri ). Desa-desa SCTPB ini telah dimasukan dalam beberapa desa wisata yang tertuang dalam SK Bupati Buleleng Nomor 430/405/HK/2017. Desa tua di Kecamatan Banjar yang telah masuk kawasan pedesaan Bali Aga saat ini sudah memulai membuka diri ( Andiani, 2020). Salah satu desa Bali Aga yang telah berkembang menjadi daya tarik wisata yaitu Desa Tigawasa. Selain memiliki keindahan alam dan budaya berupa tarian dan juga rumah adat, desa ini juga memiliki objek wisata buatan seperti Kubu Alam dan Rumah Kejapa. Daya tarik Kubu alam ini menawarkan destinasi desa wisata dengan berbagai spot swafoto dibuat dengan bambu dengan pemandangan kota Singaraja dari ketinggian, selain itu juga ditawarkan destinasi wisata agro yang memperkenalkan komoditi andalan Desa Tigawasa yaitu Kopi Bali (Bali Express 2018).

Mayoritas mata pencaharian dari masyarakat Desa Tigawasa yaitu berkebun dan juga menganyam. Dari wawancara awal dengan Bapak Made Suadarmayasa sebagai kepala Desa Tigawasa pada tanggal 1 Nopember2020, mengungkapkan bahwa sekitar 90\% masyarakat Desa Tigawasa bermata pencaharian sampingan yaitu menganyam dengan mata pencarian pokoknya yaitu berkebun. Perkebunan tersebut berupa cengkeh, kopi dan coklat. Desa Tigawasa memiliki banyak pohon bambu, hampir setiap lahan milik warga terdapat pohon bambu sebagai bahan anyaman. Dipertegas juga oleh Sanjaya, dkk (2017) kerajinan bambu Desa Tigawasa didukung oleh potensi alam yang dimiliki berupa pohon bambu yang khas dan sangat berbeda dengan bambu-bambu yang ada di pulau Bali pada umumnya. Setiap rumah warga pasti terdapat bambu yang diikat sebagai bahan anyaman yang menjadikan keunikan tersendiri bagi wisatawan yang sedang lewat.

Berbagai jenis anyaman yang dibuat oleh masyarakat Desa Tigawasa yaitu berupa sokasi, bedeg dan juga ada kreasi anyaman dengan berbagai hiasan yang dipadukan dengan berbagai motif yang unik dan menarik. Ada juga hal unik dalam pembagian menganyam, para kaum lelaki akan menganyam bedeg yaitu pekerjaan yang agak kasar sedangkan untuk kaum perempuan akan menganyam sokasi/keben. Dengan dikembangkannya Desa Tigawasa sebagai destinasi wisata menyebabkan banyak wisatawan datang berkunjung, dilihat sebelum pandemi ada sekitar 3 grup tamu datang dalam seminggu dan hal itu berimbas terhadap pengerajin anyaman yang ada di Desa Tigawasa merasakan manfaatnya seperti adanya beberapa pesanan serta pembelian produknya dari wisatawan. 
Kajian atas kerajinan bambu berbasis potensi lokal dengan berbagai motif hiasan anyaman bambu telah banyak dilakukan oleh peneliti sebelumnya, namun belum adanya penelitian tentang pengembangan souvenir desa wisata dari kerajinan lokal yang dihasilkan oleh Desa Tigawasa. Artikel ini membahas berbagai peluang dan tantangan dalam mengembangkan souvenir berbasis kerajinan lokal.

Alasan untuk dilakukannya penelitian ini, penulis mengetahui betapa berpotensinya kerajinan yang dibuat oleh masyarakat Desa Tigawasa yang dikembangkna sebagai souvenir unik dan menarik namun permasalahan yang terjadi masyarakat Desa Tigawasa belum bisa berinovasi terhadap anyaman yang dibuat sehingga produk masih monoton, padahal dari segi kualitas tidak dapat diragukan lagi dapat bersaing di pasaran. Selain itu, mengingat souvenir sangat penting ada di setiap destinasi sebagai simbol kenangan bagi setiap wisatawan sehingga Desa Tigawasa perlu mengembangkan souvenir tersebut. Dilihat juga dari beberapa penelitian sebelumnya, kebanyakan para peneliti terkait Desa Bali Aga, lebih tertarik terhadap budaya yang dimiliki seperti rumah adat atau rumah tuanya, sehingga belum ada yang meneliti tentang produk-produk Bali Aga yang bisa dijadikan sebagai souvenir. Untuk itulah perlunya pengembangan souvenir berbasis kerajinan lokal guna meningkatkan nilai jual kerajinan Desa Tigawasa, serta dapat menjadikan daya tarik wisatawan untuk datang ke Desa Tigawasa dan sebagai kenangan bagi setiap wisatawan yang datang ke Desa Tigawasa.

\section{B. METODE PENELITIAN}

Penelitian ini menggunakan metode deskriptif kualitatif yaitu dengan memaparkan hasil penelitian yang telah dilakukan mengenai peluang dan tantangan pengembangan souvenir desa wisata berbasis kerajinan lokal yang dilakukan di desa Bali Aga tepatnya di Desa Tigawasa. Dalam artikel ini data didapatkan dengan cara wawancara yaitu dengan mencari informasi dari berbagai sumber dengan memberikan pertanyaan kepada narasumber yang dituju. Selain itu, data yang diperoleh juga didapat dari dokumentasi penulis secara langsung ke Desa Tigawasa seperti ke rumah adat dan juga ke pengrajin anyaman yang ada di sekitar Desa Tigawasa. Metode penelitian ini juga membagikan kuisioner bagi pengunjung ke Desa Tigawasa khususnya ke Rumah Kejapa. Cara pengambilan sampelnya yaitu dengan menggunakan teknik purposive sampling.

Penelitian ini telah dilakukan selama satu tahun, yaitu dimulai dari Nopember 2019 sampai Nopember 2020. Beberapa materi yang digunakan untuk mengkaji penelitian ini yaitu dengan kajian literatur sehingga dapat mendukung penelitian ini terkait peluang dan tantangan pengembangan souvenir desa wisata berbasis kerajinan lokal desa wisata Tigawasa.

Selain itu, beberapa konsep yang mampu mengurai permasalahan dalam penelitian ini adalah pemahaman terhadap souvenir, pengembangan produk, dan desa wisata. Pengembangan produk menurut Riadi (2020), pengembangan produk yaitu salah satu proses perubahan terhadap produk yang sudah ada dengan mencari inovasi-inovasi, guna meningkatkan nilai produk yang sudah ada. Jadi pengembangan produk berarti meningkatkan nilai suatu produk dengan berbagai kreatifitas dan juga inovasi yang menarik, terhadap suatu produk lama yang dibuat menjadi produk baru yang lebih inovatif. Konsep ini mengurai produk yang telah ada yang dimiliki Desa Tigawasa dikembangkan dan dikonversikan menjadi produk yang lebih inovatif seperti souvenir.

Souvenir adalah benda yang dibeli berfungsi sebagai pengingat suatu pengalaman yang diproduksi secara komersial dan seringkali dihubungkan secara universal dengan turisme (Prakosa \& Cheon : 2013 dalam artikel Definisi Menurut Para Ahli). Souvenir menjadi barang sebagai pengingat seseorang datang ke suatu tempat, misal ketika berwisata ke suatu destinasi wisata atau ke desa wisata. Dalam Definisi Menurut Para Ahli souvenir dalam tempat wisata adalah barang-barang khas dari tempat tersebut dan menggambarklan daerah tersebut. Wisatawan membeli souvenir dengan tujuan untuk mengabadikan pengalaman yang diperoleh selama berada di suatu objek wisata, baik itu untuk dirinya maupun orang 
disekitarnya (Schluter, 1993). Dengan begitu suatu destinasi wisata sangat perlu adanya souvenir agar para wisatawan yang berkunjung akan terus mengingat destinasi atau tempat wisata yang dikunjungi tidak terkecuali juga pada desa wisata.

Desa wisata adalah komunitas atau masyarakatyang terdiri dari penduduk suatu wilayah yang berinteraksi secara langsung dalam pengelolaan, dan memiliki kepedulian serta kesadaran untuk memperdayakan potensi secara kondusif bagi tumbuk kembangnya suatu wilayahnya (Setiyadi, 2019). Masyarakat di suatu desa wisata menjadi pelaku utama dalam peningkatan potensi pariwisata atau daya tarik wisata yang ada di wilayahnya. Jadi desa wisata Tigawasa sebagai sentral kerajinan bambu pengrajinnya harus mampu mengembangkan produk yang dimiliki agar mampu meningkatkan daya tarik wisatawan datang ke desa wisata Tigawasa sehingga berdampak pada perkembangan pariwisata yang ada.

Teori pariwisata digunakan sebagai acuan dalam mengurai hasil penelitian. Pariwisata diartikan sebagai segala sesuatu yang berhubungan dengan wisata termasuk pengusahaan, daya tarik dan atraksi wisata serta usaha-usaha yang berhubungan dengan penyelenggaraan pariwisata, UU No. 9 Tahun 1990. Pariwisata tidak lepas dengan yang namanya daya tarik wisata, karena hal itu yang menyebabkan suatu pariwisata akan menarik untuk dikunjuungi. Hal ini juga selaras dengan Herdiana (2012) daya tarik wisata merupakan dasar bagi kepariwisataan, tanpa adanya daya tarik di suatu daerah kepariwisataan akan sulit untuk berkembang. Menurut Sunaryo ( 2013) daya tarik wisata dibagi menjadi tiga jenis yaitu wisata alam, wisata buatan dan wisata khusus. Dan daya tarik suatu destinasi wisata dapat dipengaruhi oleh tiga hal penting yaitu sesuatu yang dilihat (something to see), sesuatu yang dilakukan ( something to do), dan sesuatu yang dibeli (something to buy). Something to buy yang dimaksud ini yaitu souvenir, seperti yang ditegaskan oleh Helpiastuti (2018) Something to buy adalah fasilitas untuk wisatawan berbelanja yang produknya merupakan icon daerah tersebut serta bisa dijadikan sebagai oleh-oleh bagi wisatawan. Konsep 3 hal ini dapat dijadikan acuan terkait peluang untuk menjadikan kerajinan lokal Desa Tigawasa sebagai souvenir.

\section{HASIL DAN ANALISIS}

Beberapa penelitian terdahulu yang berkaitan dengan penelitian ini, yaitu terkait terhadap Desa Tigawasa mulai dari kerajinan bambu berbasis potensi lokal, motif serta desain anyaman bambu yang kreatif dan inovatif, hingga analisis swot dan promosi kerajinan bambu. Untuk lebih jelasnya akan dipaparkan penelitian terdahulu sebagai bahan pembanding dengan penelitian ini. Hasil penelitian terdahulu yang secara khusus terkait berbagai motif kreatif dan inovatif kerajianan, kerajinan berbasis potensi lokal di Desa Tigawasa termasuk oleh Sanjaya, dkk (2017), Putri Yuanda, dkk (2014), Muliawati (2017) dan Widianingsih (2012).

Sanjaya, dkk (2017) dalam artikelnya menjelaskan Desa Tigawasa memiliki potensi bambu yang khas yang berbeda dengan desa penghasil bambu lainnya di Bali, bambu milik Desa Tigawasa yaitu tumbuhnya lebih berkesinambungan dengan batangnya yang halus. Hal tersebut yang memberi peluang bagi Desa Tigawasa menuju one village one product (OVOP), disamping itu sokasi menjadi produk unggulan dari Desa Tigawasa dan juga dikembangkan produk seperti tempat sesajen, tempat pulpen, tas laptop, taplak meja, tempat lampu dan lain-lain. Fokus perhatian dari adanya program iptek bagi Desa Tigawasa berupa pendampingan secara berkelanjutan mengenai warga yang belajar untuk memantapkan keterampilan, sudah terbentuknya kelompok pengembangan usaha secara permanen, adanya modal dari BUMDES terkait masalah permodalan kelompok usaha.

Sedangkan dalam artikel Putri Yuanda, dkk (2014) memaparkan beberapa motif hias yang menarik dari anyaman bambu yang diproduksi di Kejapa Bamboo Handcraft, Desa Tigawasa. Motif anyaman dari Kejapa Bamboo Handcraft sangat unik dan menarik yang ditambahkan dengan motif hias dari benda lain, 
misalnya kerang, kancing, potongan kayu dan lain-lain, selain itu anyaman tersebut diterapkan di bendabenda fungsional seperti kotak tisu, tempat sampah, sandal, tas, kotak perhiasan, dompet, tempat lampu dan lain-lain, sehingga membedakan dengan anyaman dari luar Desa Tigawasa. Selaras dengan penelitian Mulyawati, (2017) yang juga menjelaskan tentang desain kreatif dan inovatif dari anyaman yang diproduksi oleh Desa Tigawasa. Penelitian ini menekankan memberikan pelatihan terhadap pengrajin anyaman Desa Tigawasa dengan menggunakan dua aspek yaitu aspek pembuatan desain yang kreatif dan inovatif dan perbaikan aspek manajemen produksi. Dengan kedua aspek tersebut memberikan kemampuan bagi pengrajin anyaman untuk mendesain produk anyaman yang melahirkan desain yang kreatif dan inovatif. Dari ketiga penelitian yang telah dilakukan belum ada yang menjelaskan tentang peluang dan tantangan pengembangan souvenir berbasis kerajianan lokal.

Penelitian terkait pengembangan anyaman serta tantangan dan peluang yaitu dalam Setiawan (2010) menjelaskan beberapa strategi pengembangan kerajinan bambu, dan salah satunya yaitu strategi pengembangan produk. Penelitian tersebut menjadi rekomendasi dalam penelitian tersebut karena memiliki Total Attractive Score (TAS) paling tinggi sebesar 7,25 dibanding dengan penetrasi pasar dan perluas pasar. Sehingga pengembangan produk menjadi penting untuk berkembangnya suatu produk kerajinan karena masyarakat akan lebih tertarik dengan produk yang baru serta kreatif.

Penelitian selanjutnya oleh Widianingsih (2012) yang menjelaskan tentang peluang kerajinan, berupa keahlian pengrajin yang mampu membuat berbagai kerajinan sehingga dapat menarik wistawan, mampu meningkatkan pendapatan warga dan nasional. Dari segi ancaman yang dihadapi yaitu produk yang masih monoton namun telah dicari strategi, yaitu strategi jangka panjang dengan cara strategi diversifikasi (produk/jasa), pengembangan produk dan desain dari kerajinan bambu agar para pembeli terus tertarik. Dari kedua hasil penelitian tersebut dapat mendukung penelitian ini, karena dengan mengetahui peluang dan tantangan sehingga dapat mengetahui pentingnya pengembangan souvenir desa wisata berbasis kerajinan lokal suatu desa wisata.

\section{Potensi Desa Wisata Tigawasa}

Desa Tigawasa adalah bagian dari desa Bali Aga, yang lokasinya di Kecamatan Banjar, yaitu $\pm 24 \mathrm{~km}$ ke barat Kota Singaraja. Lokasi desa yang berada di dataran tinggi menjadikan Desa Tigawasa memiliki suasana desa yang sejuk. Selain terkenal dengan sentral kerajinan bambunya, Desa Tigawasa juga memiliki potensi wisata yang besar. Beberapa potensi wisata yang dimiliki oleh Desa Tigawasa yaitu mulai dari alamnya yang indah serta budayanya yang merupakan warisan leluhur masyarakat Bali Aga. Potensi wisata yang dimiliki oleh Desa Tigawasa, Bali Aga tersebut menjadi suatu keindahan yang dapat dilihat oleh wisatawan yang berkunjung ke Desa Tigawasa (something to see). Berikut beberapa potensi yang dimiliki oleh desa wisata Tigawasa ;

\section{Potensi Alam}

Desa Tigawasa memiliki 4 air terjun yang indah, yaitu pertama Sasan Tegeh, air terjun ini adalah air terjun yang paling tinggi yang berada di desa sentral kerajinan bambu ini. Kedua Tibu Remeng, air terjun ini adalah air terjun yang sering dikunjungi oleh wisatawan karena memang air terjunnya yang indah, wisatawan yang ingin berkunjung ke air terjun ini perlu melakukan jalan kaki yang lumayan jauh, namun akan disuguhi dengan keindahan alam yang asri dengan pohon-pohon yang rindang. Dan air terjun ketiga dan keempat yaitu air terjun Singsing 1 dan Singsing 2 keduanya adalah air terjun yang berada dekat dengan perbatasan Desa Tigawasa dengan Desa Temukus. 


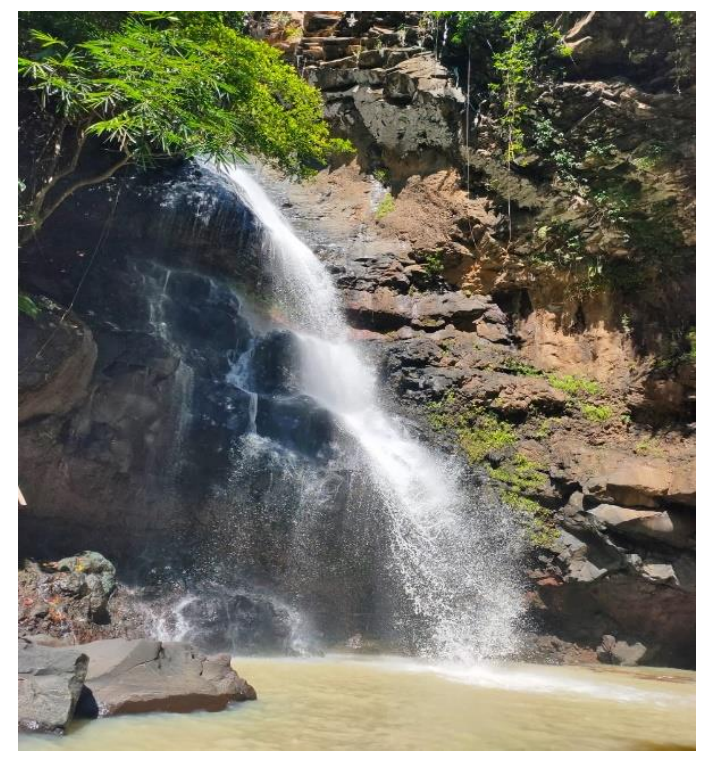

Gambar 1. Air Terjun Tibu Remeng, Desa Tigawasa, 2020 ( Foto : Gusti Ngurah Adi Wiriatama).

\section{Rumah Adat}

Rumah adat Desa Tigawasa. Setiap desa Bali Aga memeiliki rumah adat yang masih dilestarikan hingga saat ini, begitu pula dengan Desa Tigawasa. Rumah adat Desa Tigawasa memiliki keindahan arsitekturnya dengan bahan dasar tanah dan kayu. Desa Tigawasa memiliki 3 tipe rumah adat diantaranya rumah adat sekaroras, sekanem, dan sekapat. Pembedaan dari masing-masing rumah adat tersebut yaitu dari tampul/tiangnya sesuai dengan nama dari rumah adat tersebut. Rumah adat Desa Tigawasa memiliki identitas tersendiri sehingga membedakan dengan rumah adat lainnya, ketiga tipe rumah adat Desa Tigawasa memiliki kesamaan fungsi namun hanya saja pola ruang yang berbeda (Prajnawrdhi 2017). Rumah adat ini terus dipertahankan dari leluhur sampai sekarang sehingga rumah adat ini menjadi warisan budaya desa Bali Aga dan juga menjadi daya tarik wisatawan yang datang ke Desa Tigawasa.

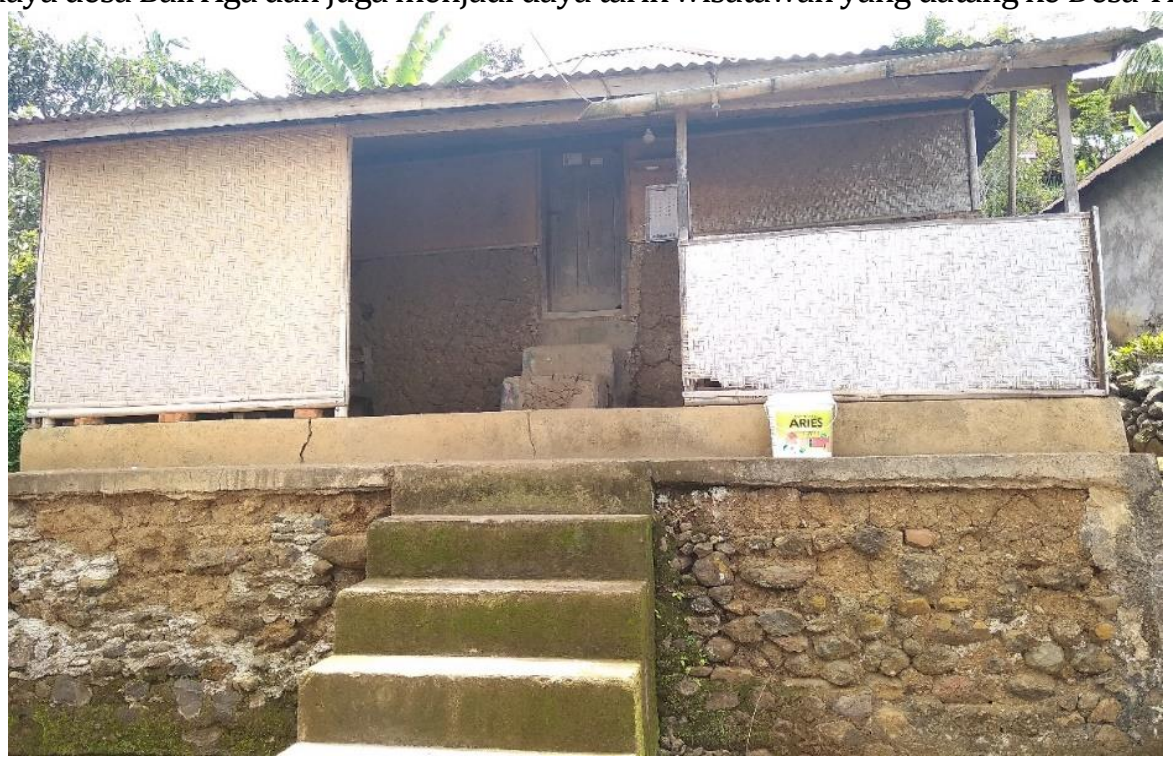

Gambar 2. Rumah Adat Sekeroras Desa Tigawasa, 2020 ( Foto : Gusti Ngurah Adi Wiriatama). 


\section{Wisata Buatan}

Desa Tigawasa selain memiliki destinasi alam serta budaya, desa ini juga memiliki wisata buatan yang tidak kalah menarik dari desa lain di Buleleng. Wisata buatan tersebut yaitu Kubu Alam dan Rumah Kejapa. Kedua wisata buatan ini di kelola oleh salah satu masyarakat Desa Tigawasa yang menjadi salah satu wisata buatan yang menarik bagi wisatawan yang berkunjung ke Desa Tigawasa.

Objek wisata kubu alam ini berlokasi di dusun Wanasara, destinasi ini memanfaatkan potensi tanaman bambu sebagai bahan bangunannya yang dibangun di lahan miliki warga. Untuk wisatawan yang datang ke objek wisata ini hanya berdonasi Rp. 10.000 sudah dapat menikmati keindahan kota Singaraja dari ketinggian, selain itu wisatawan yang datang juga bisa menikmati kuliner khas Tigawasa di rumah bambu serta bisa bersua foto dengan kerjinan yang dipamerkan di Kubu Alam ini.

Objek wisata buatan yang kedua yaitu Rumah Kejapa, pemilik Rumah Kejapa ini adalah Bapak I Gede Widarma, para wisatawan yang berkunjung ke rumah ini akan disuguhkan berbagai kegiatan seperti tracking untuk melihat perkebunan kopi dan cengkeh (somehing to see), belajar menganyam bambu (something to do) dan juga menyantap kopi dan teh serta makanan khas Tigawasa (something to buy). Rumah Kejapa ini juga meproduksi kopi khas Tigawasa dan menjadi satu-satunya produsen kopi yang ada di Desa Tigawasa.

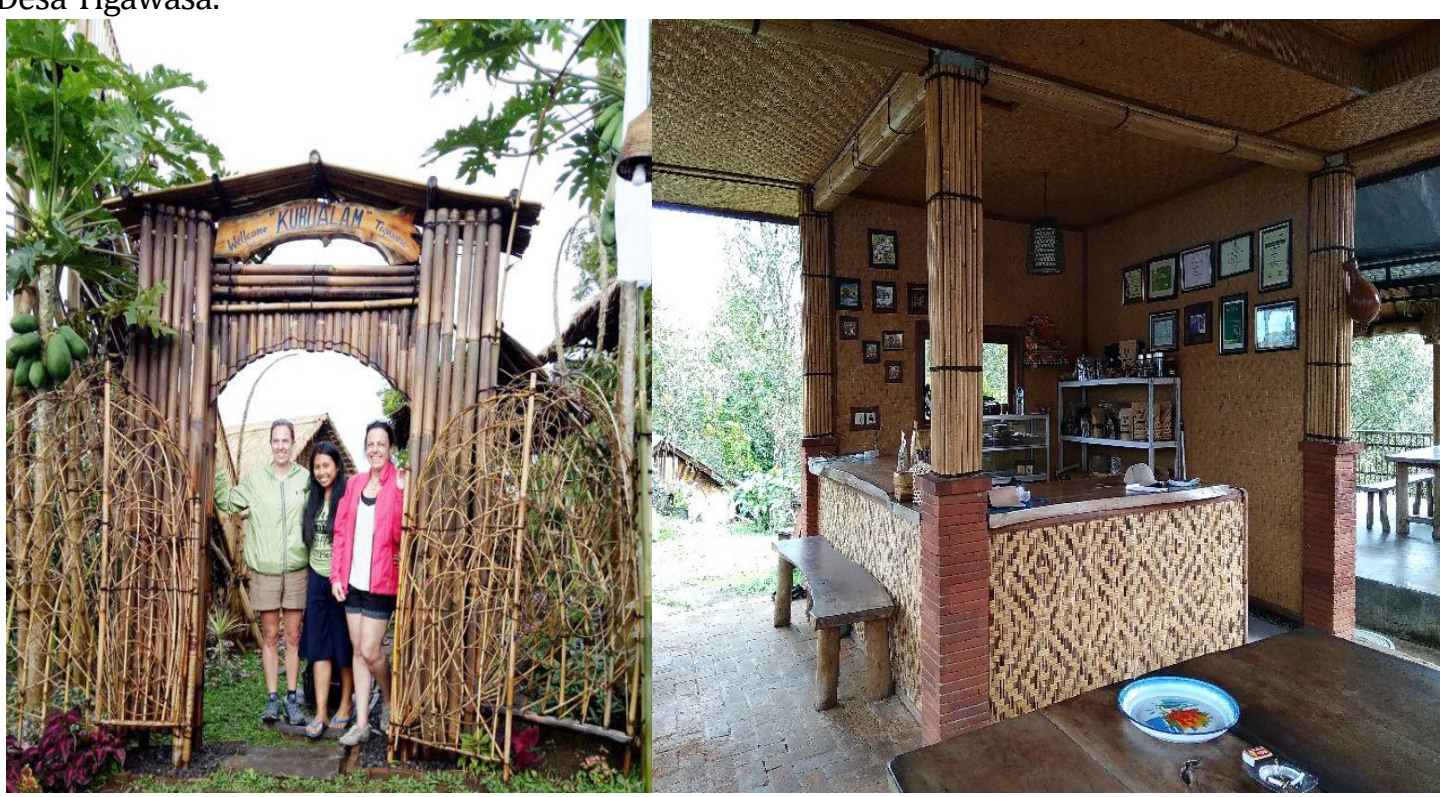

\section{Gambar 3. Kubu Alam dan Rumah Kejapa di Desa Tigawasa, 2018 ( Foto : Bisnis Bali)}

Selain itu, daya tarik wisatawan untuk datang ke Desa Tigawasa yaitu dipengaruhi juga dengan keunikan kegiatan yang dilakukan masyarakatnya. Masyarakat Desa Tigawasa setiap harinya melakukan kegiatan menganyam mulai dari anak-anak, orang dewasa maupun orang tua, hal tersebut yang menjadi daya tarik tersendiri yang dimiliki oleh desa bagian dari desa Bali Aga ini. Setiap jalan terlihat bahan anyaman bambu yang berjejer di setiap rumah warga dan warga yang sedang menganyam. Beberapa produsen kerajinan bambu pun ada di desa ini selain dari pengrajin rumahan, salah satunya yaitu Indra Bambu.

Dari hasil wawancara kepada bapak Indrayana pemilik Indra Bambu, Indra Bambu meproduksi anyaman beragam mulai sokasi dengan sibeh maupun tanpa sibeh, sokasi deko, beberapa tas dari anyaman bambu, sokasi dari ukuran besar hingga kecil sekitar $6 \mathrm{~cm}$. Produk yang dibuat yang paling laris yaitu sokasi dengan sibeh karena kualitas yang bagus serta bentuk yang unik. Beberapa produk yang 
dihasilkan telah beredar diseluruh Bali, namun sekarang biasanya dipesan dari kabupaten Tabanan, Pupuan, Klungkung,dan Singaraja.

Saat ini, pada masa pandemi covid-19 produksi kerajinan dari Indra Bambu mengalami penurunan yang sangat drastis, terlihat dari sedikit pesanan yang didapat yang biasanya pesanan sebelum pandemi covid-19 banyak hingga pesanan menumpuk namun sekarang pengrajin harus menunggu pesanan, sehingga berdampak juga bagi pemasukan pengrajin anyaman bambu yang ada di Desa Tigawasa.

Beberapa pengembangan desa terkait kerajinan pun dilakukan oleh Desa Tigawasa terlihat adanya pelatihan-pelatihan yang dilakukan terhadap pengrajin di Desa Tigawasa, dengan distrukturi oleh bapak Indrayana dengan partnernya salah satunya membuat tas dengan isi keben 4 serta mendeko sokasi. Selain itu ada pula pelatihan membuat kipas dari bambu yang unik dan kreatif. Indra Bambu juga pernah membuat inovasi baru seperti produk souvenir yang pernah dipesan sebesar 300 buah.

\section{Peluang dan Tantangan Pengembangan Souvenir Desa Wisata}

\section{Peluang}

Kegiatan menganyam sebagai salah satu komponen dalam pengembangan wisata sehingga wisatawan bisa melakukan kegiatan menganyaman bambu, kegiatan ini menjadi sesuatu yang menarik yang dilakukan oleh wisatawan. Hal ini dipertegas oleh Christiani (2018) tentang something to do, yaitu terkait dengan aktivitas yang dilakukan wisatawan di suatu daerah wisata, dengan berinteraksi langsung dalam pembuatan suatu produk.

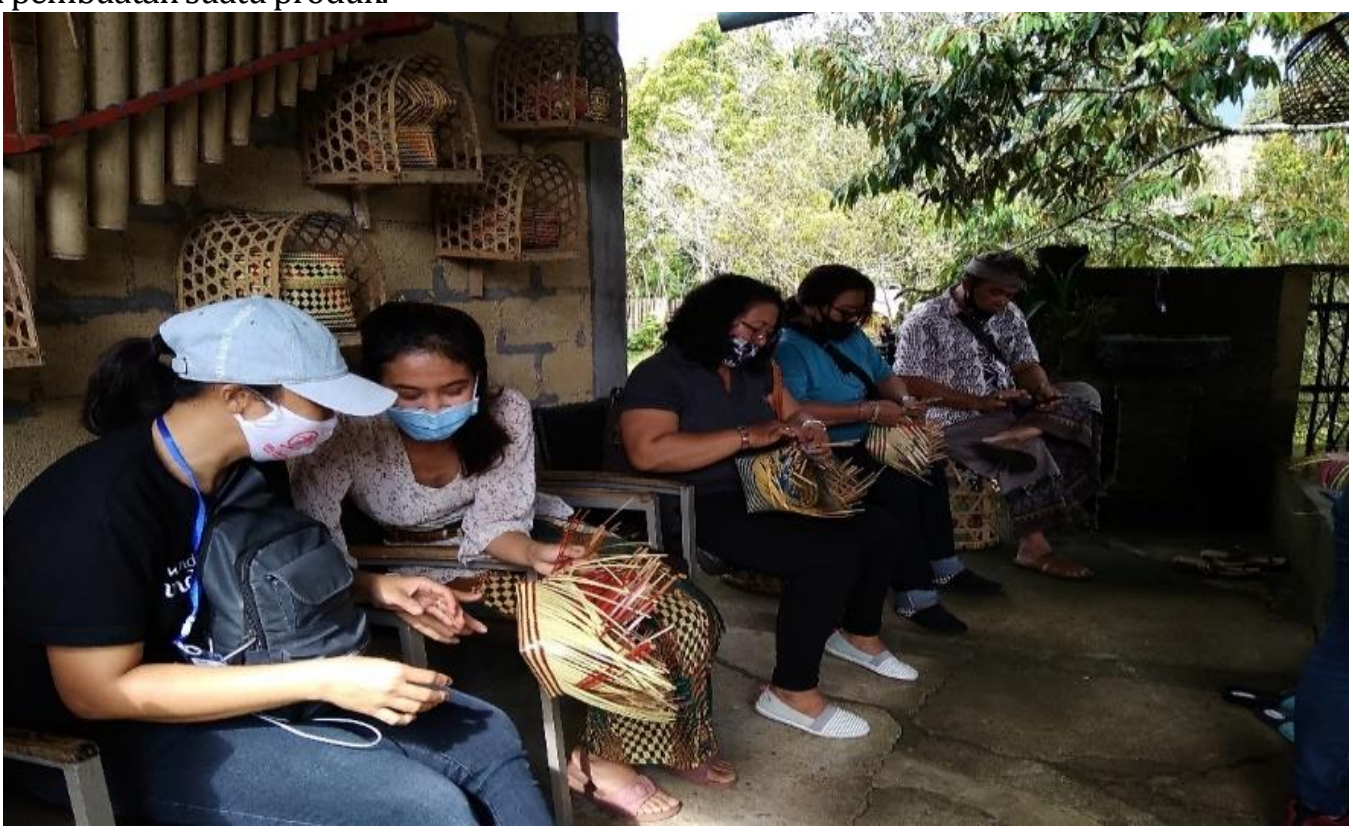

\section{Gambar 4. Wiasatawan Belajar Menganyam di Desa Tigawasa, 2020 ( Foto : Gusti Ngurah Adi Wiriatama)}

Hasil anyaman yang dibuat oleh wisatawan pada saat belajar menganyam dapat menjadi salah satu souvenir untuk dibawa pulang, hal ini juga sesuai dengan komponen pengembangan pariwisata terkait something to buy. Apa yang terjadi di desa wisata Tigawasa dipertegas pula oleh beberapa hasil penelitian terkait something to buy yaitu oleh Putri (2017), something to buy terjadi karena adanya keinginan untuk melihat (something to see), kemudian mempelajarinya, sehingga keinginan untuk memiliki (something to 
buy) hal ini terdapat kegiatan "jual beli" yaitu sebagai wujud apresiasi terhadap hasil kerajinan atau karya seni masyarakat.

Peluang yang dimiliki oleh kerajian lokal Desa Tigawasa yaitu kerajinan yang dibuat memiliki kualitas yang bagus, terlihat dari berbagai ketelitian anyamannya. Berikut hasil wawancara salah satu pengrajin anyaman bambu di Desa Tigawasa yaitu Bapak Indrayana pemilik Indra Bambu, ketika bertanya apa bedanya kerajian Desa Tigawasa dengan desa lain seperti Desa Sidatapa, Bapak Indra memberikan respon berikut.

"Kerajinan anyaman kami lebih berkualitas dari yang dibuat dari desa Sidatapa, di desa Sidatapa memang lebih murah namun dari segi kualitas kurang bagus, namun dari kerajian anyaman yang kami buat lebih mahal namun dari segi kualitas dapat dipercaya bagus, jadi harga sepadan dengan kualitas" (Wawancara 1 Nopember 2020).

Jadi kualitas anyaman bambu yang diproduksi di Desa Tigawasa memang kualitas bagus, dilihat dari kualitas bambu yang khas yang dimiliki oleh Desa Tigawasa. Selain itu banyak desa lain atau masyarakat desa lain membeli kerajinan seperti sokasi dari Desa Tigawasa karena memang kualitas yang dimiliki sangat bagus. Begitu pula yang dijelaskan dalam artikel Guntur FM, kerajinan bambu Desa Tigawasa memiliki kualitas cukup baik, produk kerajinannya pun laris dipasaran seperti sokasi yang banyak diincar konsumen.

Peluang pengembangan souvenir desa wisata juga didukung oleh wisatawan yang berkunjung ke Desa Tigawasa. Wisatawan tersebut yaitu peserta dari program Explore Buleleng yang dilaksanakan oleh Dinas Pariwisata Kabupaten Buleleng. Hasil penelitian menunjukan 70\% wisatawan menyatakan sangat setuju perlu adanya souvenir desa wisata sedangkan 30\% menyatakan setuju dan tidak adanya yang menanggapi Tidak Setuju dan Sangat Tidak Setuju.

Tabel 1. Tanggapan Wisatawan Perlu Adanya Souvenir Desa Wisata Tigawasa ( $\mathrm{N}=30$ responden)

\begin{tabular}{cccc}
\hline No. & Jumlah Responden & \multicolumn{1}{c}{ Tanggapan } & Presentasi Responden \\
\hline \multirow{3}{*}{1.} & 30 orang & Sangat Setuju & $70 \%$ \\
\cline { 3 - 3 } & & Setuju & $30 \%$ \\
\cline { 3 - 3 } & & Tidak Setuju & $0 \%$ \\
\cline { 3 - 3 } & Sangat Tidak Setuju & $0 \%$ \\
\hline & & $\mathbf{1 0 0 \%}$
\end{tabular}

Sumber : Hasil Penelitian, 2020

Berdasarkan hasil wawancara kepada salah satu wisatawan desa wisata Tigawasa yaitu Yudi Sastrawan pada tanggal 22 Nopember 2020 di Rumah Kejapa, mengungkapkan bahwa sangat senang berada di Desa Tigawasa, serta ketika diberi kesempatan untuk mencoba menganyam mulai dari mengupak bambu hingga mengayam itu sangat mengedukasi para wisatawan yang datang. Menurutnya sangat penting adanya souvenir desa wisata karena dapat memberikan kenangan bagi wisatawan yang datang ke Desa Tigawasa, selain itu kenangan menjadi salah satu bagian dari unsur "Sapta Pesona" . Souvenir sangat erat kaitannya dengan pariwisata, setiap orang yang datang ke tempat wisata dapat menemukan souvenir, setiap orang yang berkunjung pasti mebeli souvenir di daerah kunjungannya karena tidak dapat ditemui di daerah asal pengunjung dengan begitu setiap tempat pariwisata akan lebih lengkap dikunjungi jika memiliki souvenir khas daerah tersebut (Mario 2013). Hal itu yang membuat 
sangat penting adanya souvenir desa wisata agar para wisatawan dapat mengenang terus menerus terhadap desa wisata Tigawasa.

Grafik 1 merupakan endapat wisatawan terhadap kerajinan lokal desa tigawasa sebagai souvenir. Grafik Menunjukan bahwa rata-rata wisatawan yang datang ke Desa Tigawasa sangat setuju dengan adanya souvenir desa wisata dari hasil kerajinan lokal Desa Tigawasa, sehingga hal ini sangat berpeluang bagi kerajinan lokal Desa Tigawasa yang dijadikan sebagai souvenir desa wisata.

\section{Pendapat Wisatawan Terhadap Kerajinan Lokal Desa Tigawasa Sebagai Souvenir}

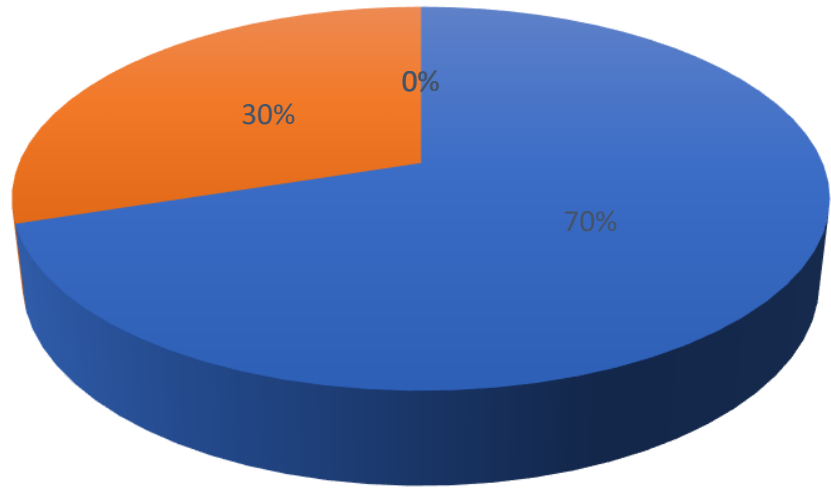

sangat setuju घ setuju $\square$ tidak setuju a sangat tidak setuju

\section{Grafik 1. Presentase Pendapat Wisatawan Terhadap Kerajinan Lokal Desa Tigawasa Sebagai Souvenir (Sumber : Hasil Penelitian, 2020).}

Untuk mengetahui souvenir yang cocok untuk dikembangkan di desa wisata Tigawasa telah ada wawancara sedikit kepada wisatawan yang datang ke Desa Tigawasa tepatnya ke Rumah Kejapa yaitu Ibu Suastini, ketika menanyakan tentang souvenir apa yang perlu dikembangkan kepada wisatawan, beliau memberikan respon berikut. "Kalau untuk souvenir desa wisata bisa pakai keben atau sokasi kecil itu sudah bagus dan unik dengan diisi tulisan seperti Desa Tigawasa atau Rumah Kejapa" ( Wawancara 22 Nopember2020).

Jadi, untuk souvenir desa wisata Tigawasa sangat bagus menggunakan keben atau sokasi selain unik dan menarik, keben atau sokasi itu adalah produk anyaman unggulan yang dimiliki oleh masyarakat Desa Tigawasa. Sehingga dengan adanya souvenir keben tersebut menjadikan souvenir khas serta icon Desa Tigawasa yang hanya bisa ditemui di Desa Tigawasa, Bali Aga.

\section{Tantangan}

Tantangan yang pertama berasal dari bahan, beberapa pengrajin memilih untuk mebeli pohon bambu di desa lain sebagai bahan anyaman, karena pohon bambu yang ada sudah semakin sedikit untuk itulah desa lain yang memiliki sumber bambu yang memadai dijadikan sebagai sumber bahan tambahan bagi pengrajin, seperti desa busungbiu. Desa Tigawasa menjunjung keseimbangan alam terbukti bahwa masyarakat tidak mau mengeksploitasi penuh pohon bambu yang ada dan mereka membiarkan pohonnya untuk tumbuh kembali, sehingga menjadikan pohon bambu khas Desa Tigawasa tetap lestari. Hal ini juga ditegaskan dalam Bali Post, pemerintah Desa Tigawasa memberikan pembinaan kelompok petani untuk sadar membudidayakan kembali bambu buluh agar bisa mengatasi krisis bahan baku yang selama ini dialami oleh setiap pengrajin anyaman di Desa Tigawasa. Dari keterbatasan bahan hingga 
membeli bahan tambahan ke desa lain, menyebabkan perlunya modal ekstra untuk membeli bahan tersebut sehingga modal juga menjadi tantangan bagi kerajinan Desa Tigawasa.

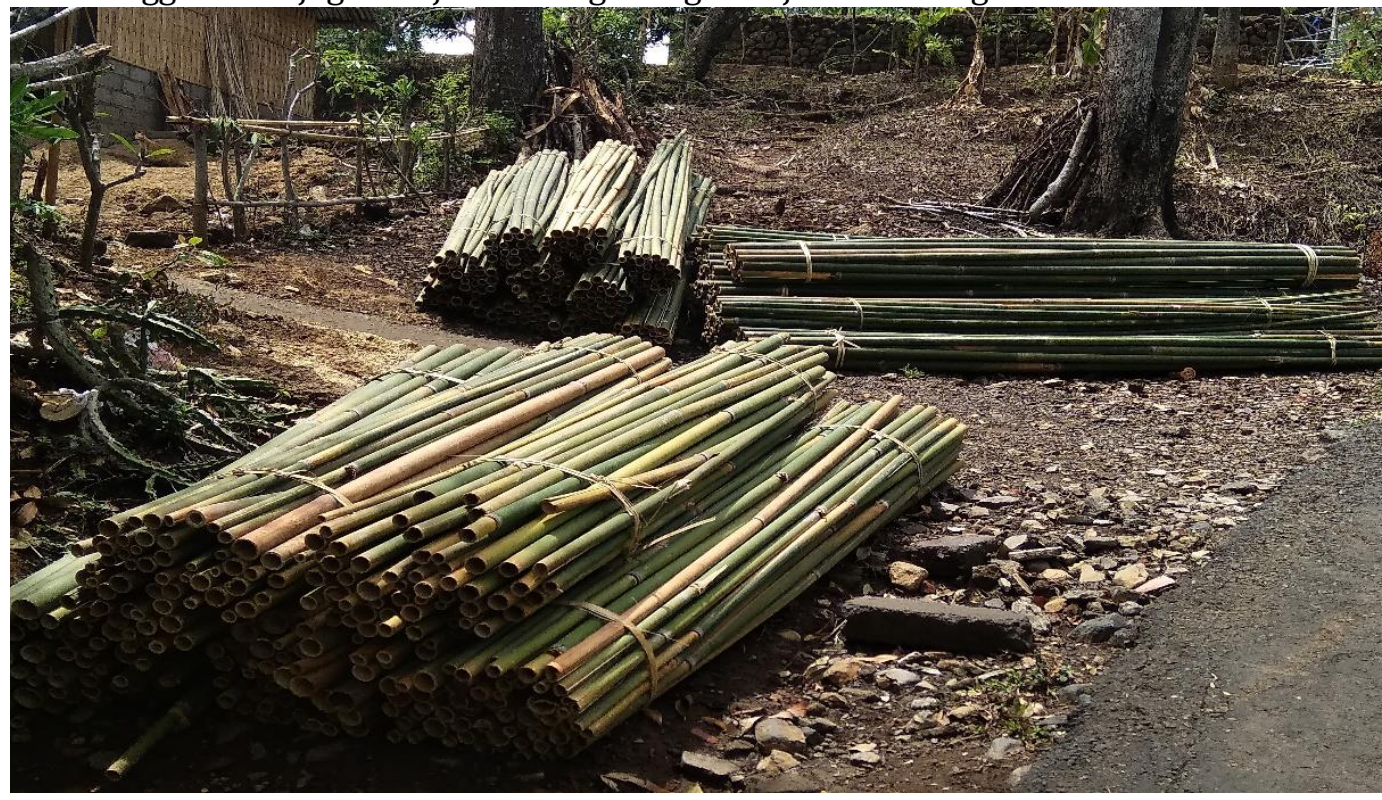

\section{Gambar 5. Bambu Sebagai Bahan Anyaman di Desa Tigawasa, 2020 ( Foto :Ngurah Adi)}

Tantangan kedua dan menjadi salah satu tantangna yang sangat besar dari kerajinan Desa Tigawasa adalah dari segi inovasi. Inovasi dari produk anyaman yang dibuat oleh Desa Tigawasa masih kurang. Beberapa anyaman masih monoton dengan produk unggulan yaitu sokasi atau keben. Pernyataan ini juga dijelaskan dalam faktapers.id bahwa keberadaan anyaman bambu di Desa Tigawasa sekarang ini kuarang eksis, disebabkan karena persaingan dengan daerah lain, pengrajin Desa Tigawasa belum berani berinovasi sehingga produk yang dihasilkan juga monoton. Namun yang menjadikan kerajinan anyaman Desa Tigawasa ini tetap bertahan karena memang kualitas dari anyaman Desa Tigawasa mampu bersaing dan juga mampu memuaskan konsumen.

Untuk itulah inovasi perlu dikembangkan dari kerajinan lokal Desa Tigawasa ini salah satunya yaitu produk souvenir desa wisata. Kita ketahui souvenir sangat diminati oleh banyak orang apalagi souvenir tersebut bersifat alami dan menarik dan didukung dengan kualitas produk anyaman yang dimiliki oleh desa ini. Dengan begitu selain dapat meningkatkan nilai jual produk anyaman, juga dapat meningkatkan pendapatan masyarakat serta meningkatkan kunjungan wisatawan untuk datang ke Desa Tigawasa nantinya. Maka dari itu sangat penting untuk pengembangan souvenir desa wisata berbasis kerajinan lokal di Desa Tigawasa.

Tantangan lain juga dari pemasaran atau promosi, pemasaran produk anyaman tersebut juga masih kurang, terlihat dari beberapa pemasaran yang dilakukan oleh pengrajin, pemasaran pun hanya menggunakan bantuan media sosial pribadi sehingga tidak begitu meluas untuk penyebaran informasi produk-produk yang dimiliki oleh desa wisata Tigawasa.

\section{SIMPULAN}

Pengembangan souvenir desa wisata berbasis kerajinan lokal di Desa Tigawasa memiliki peluang dan tantangan yang perlu perhatikan, souvenir berbasis kerajinan lokal ini menjadi peran penting untuk meningkatkan nilai produk kerajinan Desa Tigawasa, menjadi simbol kenangan bagi setiap wisatawan yang datang dan juga meningkatkan kunjungan wisatawan selain dengan keindahan desatinasi wisatanya yaitu alam berupa air terjun dan kebudayaan yang dimiliki berupa rumah adat Desa Tigawasa. Tentunya 
peluang dan tantangan tersebut perlu diatasi dengan baik agar dapat dipersiapkan agar mampu menciptakan berbagai souvenir yang unik dan kreatif berbasis keranjinan lokal Desa Tigawasa. Selain itu desa wisata Tigawasa dengan sentral kerajinan bambunya diharapkan mampu berkembang dengan baik serta dapat bermanfaat bagi kemajuan desa, dan sebagai desa wisata pilihan untuk dikunjungi oleh wisatawan.

\section{DAFTAR REFERENSI}

Andiani. Nyoman Dini. (2020). "Peran Nilai Hindu "Tri Kaya Prisudha" dalam Meningkatkan Loyalitas Wisatawan Terhadap Desa Wisata Pedawa, Bali Utara". Jurnal Kajian Bali. Vol. 10, No. 02, pp 603-626.

Bali Express . 2018. "Kubu Alam Tigawasa Ajak Wisatawan Belajar Dari Alam". Dalam: https://baliexpress.jawapos.come/read/2018/05/04/70515/kubu-alam-tigawasa-ajakwisatawan-belajar-dari-alam . Diakses 6 Nopember2020.

Bali Post. 2018. "Desa Ini Dikenal Akan Kerajinan Anyaman Bambunya". Dalam : https;//www.balipost.com/news/2018/04/15/42889/Desa-Ini-Dikenal-akanKerajinan...html. . Diakses 6 Nopember2020.

Christiani, Desi. 2018. "Analisis Artisipasi Masyarakat Dalam Memanfaatkan Objek Wisata Rotan Di Desa Trangsan, Gatak, Sukoharjo". Skipsi Ilmu ekonomi Fakultas Ekonomi dan Bisnis Universitas Sebelas Maret Surakarta.

Definisi Menurut Para Ahli. Dalam: http://www.definisimenurutparaahli.com/pengertiansouvenir/ . Diakses 2 Nopember2020.

Fakta Pers. (2020). "Majukan Potensi, Desa Tigawasa Kembali Berbenah". Dalam: https://faktapers.id/2020/09/majukan-potensi-desa-tigawasa-kembali berbenah/ . Diakses 6 Nopember2020.

Guntur FM. (2020). "Sokasi Bambu Tigawasa Laris di Pasaran". Dalam :http://www.gunturfm.com/sokasi-bambu-tigawasa-laris-dipasaran . Diakses 6 Nopember2020.

Helpiastuti, Selfi Budi. 2018. "Pengembangan Destinasi Pariwisata Kreatif Melalui Pasar Lumpur (Analisis Wacana Grand Opening "Pasar Lumpur" Kawasan Wisata Lumpur, Kecamatan Ledokombo, Kabupaten Jember)". Jurnal of Tourism and Creativity. Vol. 2, No. 1, pp 13-23.

Herdiana, Lisa. 2012. "Daya Tarik dan Kawasan Wisata". Dalam : http://lisaherdiana.blogspot.com/2012/04/daya-tarik-dan-kawasan-wisata.html?m=1 . Diakses 6 Nopember2020.

Mario, Vero, dkk. 2013. "Studi Tentang Bentuk Dan Chiri Khas Souvenir Sebagai Penunjang Pariwisata Bukitinggi". The Journal of Art Education. Vol. 2, No 1, pp 1-16.

Mulyawati, Made Ida. 2017. "Desain Yang Kreatif Dan Inovatif Kerajinan Anyaman Bambu Di Desa Tigawasa, Buleleng". Majalah Aplikasi Ipteks NGAYAH. Vol.8, No 1, pp 60-65.

Plansurgent. " Teori Pariwisata". Dalam : https://plansurgent.wordpress.com/teori-pariwisata/ . Diakses 6 Nopember2020.

Putri, Yuanda Yeni, dkk. 2014. "Motif Hias Pada Kerajinan Anyaman Bambu Di Kejapa Bamboo Handcraft, Desa Tigawasa, Kecamatan Banjar, Kabupaten Buleleng". Jurnal Pendidikan Seni Rupa. Vol 4, No 1, pp 1-10.

Putri, G.O.N.H dan Saud, Muhammad Ibnu. "Pasar Seni Kerajinan Banjarmasin". Journal of Architecture. Vol. 6, No. 1, pp 140-146.

Prajnawrdhi, T.A dan Yudantini, N.M. 2017. "Tipologi Rumah Adat Pada Desa Bali Aga Studi Kasus Pada Desa Tigawasa, Kecamatabn Banjar, Kabupaten Buleleng". Seminar Nasional Arsitektur dan Tata Ruang (SAMARTA).

Riadi, Muchlisin. 2020. "Pengembangan Produk ( Pengertian, Tujuan, Strategi dan Tahapan)". Dalam : http://www.kajianpustaka.com/2020/03/pengembangan-produk.html?m=1 .Diakses 6 Nopember2020.

Sanjaya, Dewa Bagus, dkk. 2017. "Kerajinan Bambu Warga Belajar Berbasis Potensi Lokal Di Desa Tigawasa". Dalam 
http://eproceeding.undiksha.ac.id/index.php/senadimas/article/download/1049/804/ . Diakses 2 Nopember2020.

Schluter, R. G. (1997). The Role of T-shirts In The Creation of Tourist Destination Image, Estudios $y$ perspectivas en turismo, 7, 5-23.

Setiawan, Budi. 2010. "Strategi Pengembangan Usaha Kerajinan Bambu di Wilayah Kampung Pajeleran Sukahati Kecamatan Cibinong Kabupaten Bogor". Jurnal Manajemen dan Organisasi. Vol 1, No. 2, pp 135-147.

Setiyadi, Yudi. 2019. "Pengertian Desa Wisata dan Konsep Pengembangannya". Dalam : https://ensiklo.com/2019/10/21/pengertian-desa-wisata/ . Diakses 6 Nopember2020.

Sunaryo, B. (2013). Kebijakan Pembangunan Destinasi Pariwisata Konsep dan Aplikasi di Indonesia. Yogyakarta : Gava Media.

Widyaningsih, Heni. 2012. " Analisis Swot dan Promosi Kerajinan Bambu DesaWisata Brajan Kabupaten Yogyakarta”. Jurnal Pariwisatadan Budaya. Vol. 3 No 2, pp. 1-9. 
Perkembangan jasa perhotelan saat ini sedang mengalami persaingan yang sangat ketat, seiring meningkatnya perkembangan layanan jasa perhotelan yang dari tahun ke tahun semakin meningkat. Persaingan dapat dilihat dari kualitas, pelayanan, harga dan cara promosi pada masing - masing perusahaan. Menurut Zarkowi \& Widiartanto (2016) menyatakan bahwa "Persaingan semakin ketat, maka membutuhkan perubahan paradigma yang awalnya berbasis sumber daya (resource - based) menjadi berbasis pengetahuan (knowledge - based) yang bertumpu pada bidang analisis ilmu pengetahuan dan disertai dengan peningkatan sumber daya manusia". Di era kompetisi saat ini diharapkan para pelaku usaha dapat mendorong usahanya agar semakin kokoh dalam membangun kemampuan bersaingnya bukan hanya tingkat dosmetik, tetapi regional maupun global, karena akan muncul layanan - layanan kompetitif yang sangat terjangkau dengan harga dan kualitas yang baik.

Menurut Putra (2013) menambahkan bahwa "Motivasi karyawan merupakan salah satu strategi untuk meningkatkan kinerja karyawan". Suatu perusahaan akan dituntut untuk memiliki produktivitas yang baik agar dapat mencapai target yang sudah ditentukan oleh perusahaan. Karyawan harus memiliki pengetahuan dan sikap dalam berkomunikasi, sehingga pergeseran paradigma akan membawa potensi dalam menggerakkan perusahaan dengan bertumbuhnya kesadaran dari pelaku bisnis tentang aset pengetahuan. Manajemen pengetahuan merupakan aspek penting dalam sebuah perusahaan, agar dapat berjalan secara efektif dan stabil. Menurut Iskandar \& Subekan (2018) menyebutkan bahwa "Pengetahuan ada dua jenis, yaitu pengetahuan terbatinkan (tacit knowledge) dan pengetahuan sudah terekam yang termodifikasi dalam dokumen (explicit knowledge)". Penerapan manajemen pengetahuan dalam dunia bisnis dapat meningkatkan kinerja sumber daya manusia dengan melalui penilaian karyawan.

Menurut Hayati (2020) menyatakan bahwa "Dukungan Organisasi didefinisikan sebagai sejauh mana pegawai percaya bahwa organisasi dapat menghargai kontribusi mereka dan peduli terhadap kesejahteraan mereka". Jika karyawan menganggap bahwa dukungan organisasi yang diterimanya tinggi, maka karyawan tersebut akan menyatukan keanggotaannya sebagai anggota organisasi ke dalam identitas dirinya dan akan mengembangkan hubungan persepsi yang lebih positif terhadap organisasi. Menurut Hayati (2020) menyatakan bahwa "Komitmen diatas akan mendorong karyawan untuk membantu organisasi dalam mencapai tujuannya, dan dapat meningkatkan harapan bahwa performa kerja akan diperhatikan dan dihargai oleh organisasi".

Visi dan misi suatu perusahaan akan tercapai apabila perusahaan dapat meningkatkan kinerja karyawan mereka. Menurut Putra (2013) menyatakan bahwa "Baik buruknya kondisi kinerja perusahaan akan mempengaruhi tercapainya keuntungan perusahaan". Menurut Tina Febriani \& Desi Indrawati (2013) menyatakan bahwa "Dalam dunia usaha yang berkompetensi secara global, maka perusahaan akan memerlukan kinerja karyawan yang tinggi". Karyawan berhak mendapatkan umpan balik atas kinerja yang telah mereka berikan terhadap perusahaan. Menurut Nugroho (2013) menyatakan bahwa "Kinerja (performance) yang berarti prestasi kerja, pelaksanaan kerja, dan pencapaian kerja. Kinerja sangat penting untuk organisasi karena kinerja karyawan yang mengarahkan bisnis menuju arah yang lebih sukses".

Menurut Miskiani \& Bagia (2021) menyatakan bahwa "Sumber daya manusia mempunyai peranan penting dalam suatu organisasi, oleh sebab itu sumber daya manusia sebagai penentu tujuan organisasi, tanpa peran manusia secanggih apapun teknologi yang dimiliki oleh organisasi maka hal tersebut tidak ada manfaatnya jika tidak digerakkan oleh tenaga manusia". Keberhasilan suatu perusahaan akan dipengaruhi oleh sumber daya manusia yang unggul agar dapat memudahkan perusahaan dalam bersaing di dunia bisnis saat ini.

Permasalahan tentang kinerja karyawan dapat dijumpai di berbagai perusahaan, salah satunya di Hotel Chanti Semarang, kurangnya dorongan dalam diri karyawan dapat menyebabkan karyawan tidak 
maksimal dalam bekerja. Maka diperlukan motivasi kerja, manajemen pengetahuan dan dukungan organisasi agar dapat membangkitkan semangat karyawan dalam bekerja. Dalam hal pengetahuan pribadi, karyawan tidak menerapkan pengalaman yang mereka miliki, dan cenderung mengabaikan pengalaman yang mereka dapatkan selama bekerja. Padahal pengalaman tersebut dapat meningkatkan pengetahuan, kemampuan dan mendukung kinerja mereka. Rumusan masalah tersebut sebagai berikut 1. Bagaimana motivasi kerja berpengaruh terhadap kinerja karyawan Hotel Chanti Semarang ? 2. Bagaimana manajemen pengetahuan berpengaruh terhadap kinerja karyawan Hotel Chanti Semarang ? 3. Bagaimana dukungan organisasi berpengaruh terhadap kinerja karyawan Hotel Chanti Semarang ? 4. Bagaimana motivasi kerja, manajemen pengetahuan dan dukungan organisasi berpengaruh terhadap kinerja karyawan Hotel Chanti Semarang ? 5.Variabel manakah yang paling berpengaruh terhadap kinerja karyawan Hotel Chanti Semarang?

\section{E. METODE PENELITIAN}

Metode penelitian yang digunakan adalah metode penelitian kuantitatif, faktual dan aktual dengan membuat angket kepada responden yang akan menjawab pertanyaan tentang pengaruh motivasi kerja, manajemen pengetahuan dan dukungan organisasi terhadap kinerja karyawan Hotel Chanti Semarang. Jumlah populasi dan sampel dalam penelitian ini adalah 64 orangyang merupakan karyawan Hotel Chanti Semarang. Uji validitas adalah suatu ukuran yang menunjukan tingkat - tingkat kevalidan suatu instrumen (Mahendra, 2015) sedangkan uji reliabilitas adalah derajat konsistensi dan stabilitas data dalam interval waktu tertentu (Mahendra, 2015). Teknik pengumpulan data menggunakan teknik kuesioner dengan membuat serangkaian pernyataan yang terkait dengan Motivasi Kerja, Manajemen Pengetahuan, Dukungan Organisasi dan Kinerja Karyawan. Sedangkan skala pengukuran menggunakan skala Likert, dengan pilihan kategori : Sangat setuju (SS), Setuju (S), Kurang setuju (KS), Tidak setuju (TS), Sangat tidak setuju (STS). Adapun rumus persamaan Linear Berganda :

$$
y=a+b_{1} x_{1}+b_{2} x_{2}+b_{3} x_{3}+e
$$

Keterangan :

$$
\text { a }
$$

$b_{1} b_{2} b_{3}$

$\mathrm{x}_{1}$

$\mathrm{X}_{2}$

$\mathrm{X}_{3}$

e
= Kinerja Karyawan (variabel dependen)

= konstanta persamaan regresi

= Koefisien Regresi Parsial

= Motivasi Kerja

= Manajemen Pengetahuan

$=$ Dukungan Organisasi

$=$ error

\section{F. HASIL DAN ANALISIS}

\section{Deskripsi Responden}

Tabel 1. Identitas responden berdasarkan jenis kelamin

\begin{tabular}{|c|l|c|c|}
\hline No. & Jenis Kelamin & Jumlah (Responden) & Presentase (\%) \\
\hline 1. & Laki - Laki & 48 & $75 \%$ \\
\hline 2. & Perempuan & 16 & $25 \%$ \\
\hline \multicolumn{2}{|c|}{ Jumlah } & 64 & $100 \%$ \\
\hline
\end{tabular}

Sumber : Data Primer diolah 2021

Dari data karakteristik responden berdasarkan jenis kelamin pada tabel 1, maka jumlah responden terbesar adalah laki - laki yaitu sebanyak 48 responden atau (75\%), sedangkan jumlah responden 
terendah adalah responden yang berjenis kelamin perempuan sebanyak 16 responden atau (25\%). Maka dapat disimpulkan bahwa sebagian besar responden berjenis kelamin laki - laki.

Tabel 2 Identitas responden berdasarkan usia

\begin{tabular}{|l|l|l|l|}
\hline No. & Umur Responden & Jumlah (Responden) & Presentase (\%) \\
\hline 1. & $<30$ th & 29 & $45,3 \%$ \\
\hline 2. & $31-40$ th & 16 & $25,0 \%$ \\
\hline 3. & $41-50$ th & 19 & $29,7 \%$ \\
\hline Jumlah & 64 & $100 \%$ \\
\hline
\end{tabular}

Sumber : Data Primer diolah 2021

Dari data karakteristik responden berdasarkan usia pada tabel 2 diatas, maka jumlah responden terbesar dengan kategori umur $<30$ th sebanyak 29 responden atau (45,3\%), umur $41-50$ th sebanyak 19 responden atau $(29,7 \%)$ dan umur $31-40$ th sebanyak 16 responden atau $(25,0 \%)$. Maka dapat disimpulkan bahwa sebagian besar responden berusia $<30$ th.

Tabel 3 Identitas responden berdasarkan tingkat pendidikan

\begin{tabular}{|l|l|l|l|}
\hline No. & Tingkat Pendidikan & Jumlah (Responden) & Presentase (\%) \\
\hline 1. & SMA/SMK & 14 & $21,9 \%$ \\
\hline 2. & D1 & 7 & $10,9 \%$ \\
\hline 3. & D3 & 21 & $32,8 \%$ \\
\hline 4. & S1 & 22 & $34,4 \%$ \\
\hline Jumlah & 64 & $100 \%$ \\
\hline
\end{tabular}

Sumber : Data Primer diolah 2021

Dari data karakteristik responden berdasarkan tingkat pendidikan pada tabel 3, maka jumlah responden terbesar dengan kategori pendidikan S1 sebanyak 22 responden atau $(34,4 \%)$, pendidikan D3 sebanyak 21 responden atau (32,8\%), pendidikan SMA/SMK sebanyak 14 responden atau (21,9\%), dan pendidikan D1 sebanyak 7 responden atau $(10,9 \%)$. Maka dapat disimpulkan bahwa sebagian besar responden berpendidikan terakhir S1.

\section{Uji Validitas dan Uji Reabilitas}

Pengumpulan data dari kuesioner dibagikan kepada 64 responden di Hotel Chanti Semarang, dan data tersebut kemudian di olah di dalam program SPSS (Statistical Product and Service Solution) untuk membuktikan keabsahan data melalui uji validitas dan reliabilitas. Uji validitas pada penelitian ini menggunakan korelasi Product Moment Person, yaitu dengan tingkat nilai r tabel sebesar $5 \%(0,05)$. Hasil olah data uji validitas ini menggunakan SPSS dengan jawaban pada tabel berikut ini :

Tabel 4 Hasil Uji Validitas

\begin{tabular}{|l|l|l|l|l|}
\hline Variabel & Indikator & $\begin{array}{l}\text { Person Correlation (r } \\
\text { hitung) }\end{array}$ & $\begin{array}{l}\text { Df=N2 } \\
\text { r tabel }\end{array}$ & Keterangan \\
\hline Motivasi Kerja $\left(\mathrm{X}_{1}\right)$ & 1 & 0,659 & 0,2075 & Valid \\
\cline { 2 - 5 } & 2 & 0,763 & 0,2075 & Valid \\
\cline { 2 - 5 } & 3 & 0,793 & 0,2075 & Valid \\
\cline { 2 - 5 } & 4 & 0,679 & 0,2075 & Valid \\
\hline \multirow{3}{*}{$\begin{array}{l}\text { Manajemen } \\
\text { Pengetahuan }\left(\mathrm{X}_{2}\right)\end{array}$} & 1 & 0,655 & 0,2075 & Valid \\
\cline { 2 - 5 } & 2 & 0,818 & 0,2075 & Valid \\
\cline { 2 - 5 } & 3 & 0,681 & 0,2075 & Valid \\
\cline { 2 - 5 } & 4 & 0,737 & 0,2075 & Valid \\
\hline
\end{tabular}




\begin{tabular}{|l|l|l|l|l|}
\hline Dukungan & 1 & 0,746 & 0,2075 & Valid \\
\cline { 2 - 5 } Organisasi $\left(\mathrm{X}_{3}\right)$ & 2 & 0,835 & 0,2075 & Valid \\
\cline { 2 - 5 } & 3 & 0,687 & 0,2075 & Valid \\
\cline { 2 - 5 } & 4 & 0,759 & 0,2075 & Valid \\
\hline \multirow{3}{*}{$\begin{array}{l}\text { Kinerja Karyawan } \\
\text { Y }\end{array}$} & 1 & 0,606 & 0,2075 & Valid \\
\cline { 2 - 5 } & 2 & 0,640 & 0,2075 & Valid \\
\cline { 2 - 5 } & 3 & 0,651 & 0,2075 & Valid \\
\cline { 2 - 5 } & 4 & 0,675 & 0,2075 & Valid \\
\cline { 2 - 5 } & 5 & 0,647 & 0,2075 & Valid \\
\cline { 2 - 5 } & 6 & 0,650 & 0,2075 & Valid \\
\hline
\end{tabular}

Sumber : Data Primer diolah 2021

Berdasarkan tabel 4 menunjukkan bahwa nialai $\mathrm{r}$ hitung setiap indikator lebih besar dari $\mathrm{r}$ tabel $=$ $0,2075(\mathrm{~N}-2=64-2=62$, sig 0,05$)$ yang berarti indikator - indikator tersebut dinyatakan valid. Uji reabilitas ini dilakukan dengan bantuan program spss dengan Cronbach Alpha sebesar 0,60 dengan ketentuan apabila Cronbach Alpha $>0,60$ maka suatu variabel dinyatakan reliable. Apabila Cronbach Alpha $<0,60$ maka suatu variabel dinyatakan tidak reliabel.

Tabel 5 Hasil Uji Reabilitas

\begin{tabular}{|l|l|l|l|l|}
\hline \multicolumn{1}{|c|}{ Variabel } & \multicolumn{1}{c|}{ Cronbach Alpha } & \multicolumn{1}{c|}{$>$} & \multicolumn{1}{c|}{ Ketetapan } & \multicolumn{1}{c|}{ Keterangan } \\
\hline Motivasi Kerja $\left(\mathrm{X}_{1}\right)$ & 0,699 & $>$ & 0,60 & Reliabel \\
\hline $\begin{array}{l}\text { Manajemen } \\
\text { Pengetahuan }\left(\mathrm{X}_{2}\right)\end{array}$ & 0,698 & $>$ & 0,60 & Reliabel \\
\hline $\begin{array}{l}\text { Dukungan Organisasi } \\
\left(\mathrm{X}_{3}\right)\end{array}$ & 0,749 & $>$ & 0,60 & Realiabel \\
\hline Kinerja Karyawan $(\mathrm{Y})$ & 0,716 & $>$ & 0,60 & Realiabel \\
\hline
\end{tabular}

Sumber : Data Primer diolah 2021

Berdasarkan tabel 5 hasil uji reabilitas dapat disimpulkan bahwa variabel - variabel yang digunakan dalam penelitian ini adalah reliabel, karena setiap variabel memiliki nilai Alpha Cronbach > 0,60 .

\section{Pengujian Hipotesis}

Tabel 6 Hasil Analisis Regresi Linear Berganda

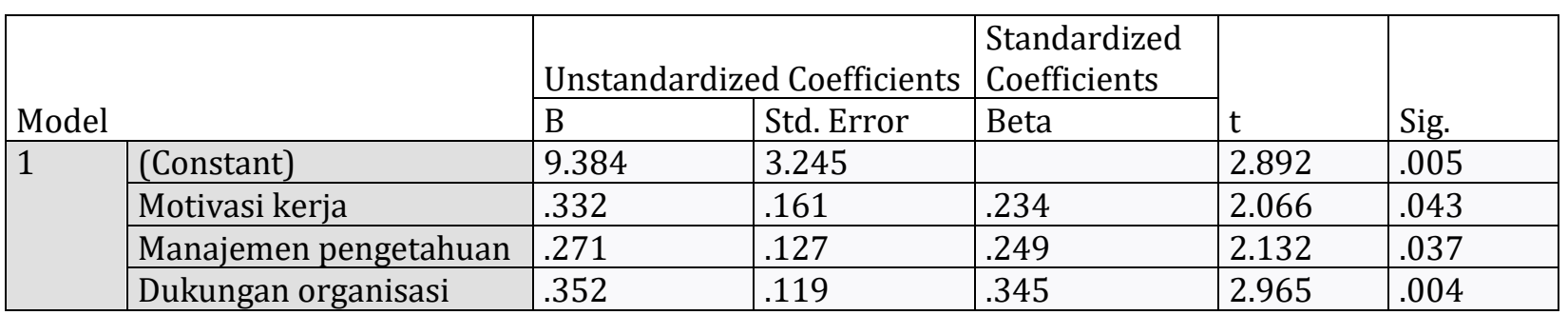

Sumber : Output SPSS 2021

Maka berdasarkan tabel persamaan regresi linear berganda yang diperoleh adalah sebagai berikut: $y=9,384+0,332 x_{1}+0,271 x_{2}+0,352 x_{3}+e$

Dari persamaan tersebut diperoleh keterangan sebagai berikut : 
1. Nilai konstanta sebesar 9,384 menunjukkan bahwa variabel - variabel independen (Motivasi Kerja, Manajemen Pengetahuan dan Dukungan Organisasi) diasumsikan konstan (0). Maka variabel dependen (Kinerja Karyawan) yaitu sebesar 9,384.

2. Koefisien variabel Motivasi Kerja sebesar 0,332 berarti setiap kenaikan motivasi kerja sebesar 1 poin, maka kinerja karyawan akan naik sebesar 0,332 dengan asumsi variabel lain tetap.

3. Koefisien variabel Manajemen Pengetahuan sebesar 0,271 berarti setiap kenaikan manajemen pengetahuan sebesar 1 poin, maka kinerja karyawan akan naik sebesar 0,271 dengan asumsi variabel lain tetap.

4. Koefisien variabel Dukungan Organisasi sebesar 0,352 berarti setiap kenaikan dukungan organisasi sebesar 1 poin, maka kinerja karyawan akan naik sebesar 0,352 dengan asumsi variabel lain tetap.

Tabel 7 Hasil Uji t

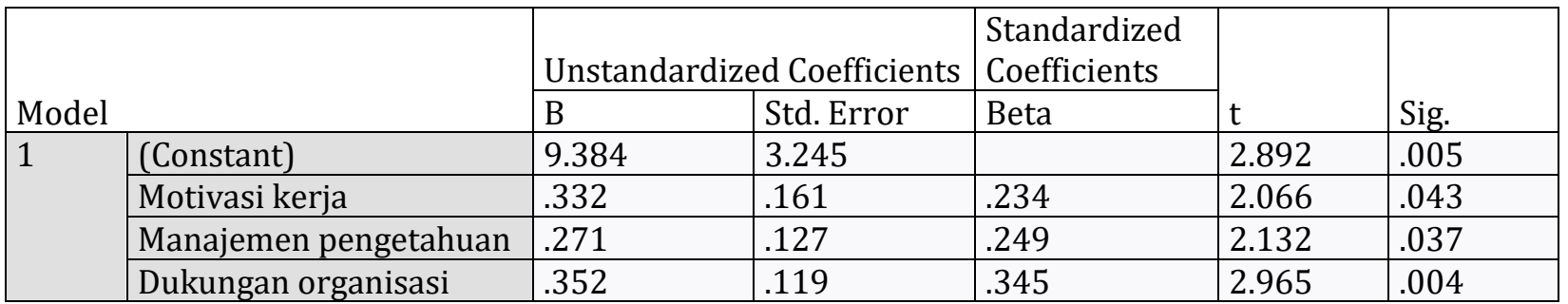

Sumber : Output SPSS 2021

Hasil dari uji t berdasarkan tabel 7 dapat disimpulkan sebagai berikut :

1. Hipotesis $1\left(\mathrm{H}_{1}\right)$ yang menyatakan bahwa motivasi kerja berpengaruh signifikan terhadap kinerja karyawan diterima, karena nilai signifikan yang diperoleh lebih kecil dari 0,05 yaitu $0,043<0,05$.

2. Hipotesis $2\left(\mathrm{H}_{2}\right)$ yang menyatakan bahwa manajemen pengetahauan berpengaruh signifikan terhadap kinerja karyawan diterima, karena nilai signifikan yang diperoleh lebih kecil dari 0,05 yaitu $0,037<0,05$.

3. Hipotesis $3\left(\mathrm{H}_{3}\right)$ yang menyatakan bahwa dukungan organisasi berpengaruh signifikan terhadap kinerja karyawan diterima, karena nilai signifikan yang diperoleh lebih kecil dari 0,05 yaitu $0,004<0,05$.

6. $\quad U j i F$

Tabel 8 Uji F

ANOVA $^{\mathbf{a}}$

\begin{tabular}{|c|c|c|c|c|c|c|}
\hline \multicolumn{2}{|c|}{ Model } & $\begin{array}{ll}\text { Sum } & \text { of } \\
\text { Squares }\end{array}$ & Df & Mean Square & $\mathrm{F}$ & Sig. \\
\hline \multirow[t]{3}{*}{1} & Regression & 86.950 & 3 & 28.983 & 8.089 & $.000^{\mathrm{b}}$ \\
\hline & Residual & 214.987 & 60 & 3.583 & & \\
\hline & Total & 301.938 & 63 & & & \\
\hline
\end{tabular}

Sumber : Output SPSS 2021

Berdasarkan tabel 8 diatas terlihat bahwa nilai F hitung sebesar 8.089 dengan nilai signifikasi 0,000 . Nilai signifikan $0.000<0,05$ maka dapat disimpulkan bahwa model regresi dalam penelitian ini merupakan model yang fit atau diterima. 


\section{Koefisien Determinasi $\left(R^{2}\right)$}

\section{Tabel 9 Hasil Uji Koefisien Determinasi}

\section{Model Summary}

\begin{tabular}{|l|l|l|l|l|}
\hline Model & $\mathrm{R}$ & R Square & $\begin{array}{l}\text { Adjusted } \\
\text { Square }\end{array}$ & $\begin{array}{l}\text { Std. Error of } \\
\text { the Estimate }\end{array}$ \\
\hline 1 & $.537 \mathrm{a}$ & .288 & .252 & 1.893 \\
\hline
\end{tabular}

Sumber : Output SPSS 2021

Dari tabel 9 angka koefisien Determinasi $\left(\mathrm{R}^{2}\right)$ sebesar 0,252 ini berarti bahwa motivasi kerja, manajemen pengetahuan dan dukungan organisasi mempunyai peranan $25,2 \%$ secara bersama - sama untuk dapat menjelaskan atau menerangkan variabel kinerja karyawan. Sedangkan sisanya 74,5 \% (100 $\%$ - 25,2 \%) dijelaskan oleh variabel lain yang mempengaruhi kinerja karyawan.

\section{G. Pembahasan}

\section{Pengaruh Motivasi Kerja Terhadap Kinerja Karyawan}

Berdasarkan hasil penelitian uji hipotesis yang pertama menunjukkan bahwa motivasi kerja berpengaruh signifikan terhadap kinerja karyawan karena motivasi kerja memiliki nilai koefisien positif sebesar 2,066 dan nilai signifikan sebesar 0,043. Hal ini telah sesuai dengan penelitian yang di lakukan oleh Muliharta (2015) menyatakan bahwa motivasi kerja berpengaruh positif dan signifikan terhadap kinerja karyawan. Motivasi kerja berperan sebagai pendorong agar karyawan lebih giat dalam bekerja. Apabila pimpinan memberikan motivasi kerja yang positif, maka karyawan akan merasa senang dan dihargai dalam bekerja.

Menurut Pamulang (2021) motivasi adalah dorongan untuk menggerakkan sebuah potensi sumber daya manusia agar mau bekerja untuk melakukan suatu pekerjaan yang berlangsung secara sadar. Berdasarkan pengertian diatas diharapkan Hotel Chanti Semarang dapat memberikan motivasi, agar kinerja karyawan akan lebih meningkat. Motivasi sebagai variabel penting, karena kinerja karyawan yang dihasilkan baik maupun buruk tergantung dari motivasi yang diterima oleh karyawan.

\section{Pengaruh Manajemen Pengetahuan Terhadap Kinerja Karyawan}

Berdasarkan hasil penelitian uji hipotesis yang kedua menunjukkan bahwa manajemen pengetahuan berpengaruh signifikan terhadap kinerja karyawan karena manajemen pengetahuan memiliki nilai koefisien positif sebesar 2,132 dan nilai signifikan sebesar 0,037. Hal ini telah sesuai dengan penelitian yang di lakukan oleh Zarkowi \& Widiartanto (2016) bahwa semakin kuat dukungan manajemen pengetahuan yang dimiliki oleh karyawan maka akan semakin mempengaruhi meningkatnya kinerja karyawan.

Menurut Oktavian (2021) Manajemen Pengetahuan dipandang penting dalam rangka mentransfer pengetahuan, keterampilan dan perilaku kerja efektif. Berdasarkan pengertian diatas diharapkan Hotel Chanti Semarang dapat memberikan manajemen pengetahuan yang sesuai, agar kinerja karyawan akan lebih meningkat. Kinerja karyawan yang dihasilkan baik maupun buruk tergantung dari manajemen pengetahuan yang diberikan kepada karyawan.

\section{Pengaruh Dukungan Organisasi Terhadap Kinerja Karyawan}


Berdasarkan hasil penelitian uji hipotesis yang ketiga menunjukkan bahwa manajemen pengetahuan berpengaruh signifikan terhadap kinerja karyawan karena manajemen pengetahuan memiliki nilai koefisien positif sebesar 2,965 dan nilai signifikan sebesar 0,004 . Hal ini telah sesuai dengan penelitian terdahulu yang dilakukan oleh Dana \& Dewi (2016) menyatakan bahwa dukungan organisasi memiliki pengaruh signifikan terhadap kinerja karyawan. Semakin besar dukungan organisasi yang diberikan, maka akan semakin baik kinerja yang dihasilkan oleh karyawan.

Fata (2020) dukungan organisasi merupakan kesiapan organisasi dalam menghargai peningkatan kinerja, dan mengembangkan keyakinan karyawan secara global bahwa sejauh mana organisasi menghargai kontribusi dan kepedulian tentang kesejahteraan karyawan. Berdasarkan pengertian diatas diharapkan Hotel Chanti Semarang dapat memberikan dukungan organisasi yang sesuai, agar kinerja karyawan mereka lebih meningkat. Kinerja karyawan yang dihasilkan baik maupun buruk tergantung dari dukungan organisasi yang diberikan oleh pihak manajemen.

\section{Pengaruh Motivasi Kerja, Manajemen Pengetahuan dan Dukungan Organisasi Terhadap Kinerja Karyawan}

Berdasarkan hasil penelitian uji hipotesis yang keempat menunjukkan bahwa ada pengaruh positif dari variabel motivasi kerja, manajemen pengetahuan dan dukungan organisasi terhadap kinerja karyawan dimana nilai $\mathrm{F}$ sebesar 8,089 yaitu dengan tingkat signifikasi 0,000 dimana nilai signifikan ini lebih kecil dari 0,005 sehingga hipotesis keempat yang diajukan ada pengaruh positif dan signifikan antara motivasi kerja, manajemen pengetahuan dan dukungan organisasi secara bersama - sama kepada kinerja karyawan dapat diterima. Hal ini dikarenakan karyawan merasa motivasi kerja, manajemen pengetahuan dan dukungan organisasi yang diberikan oleh pihak manajemen hotel sudah cukup baik. Menurut Rozalia (2015) Kinerja Karyawan adalah hasil kerja yang diraih oleh seseorang dalam melaksanakan tugas kerja yang diberikan kepadanya. Oleh karena itu pihak manajemen hotel harus memberikan motivasi kerja, manajemen pengetahuan dan dukungan organisasi agar karyawan melakukan pekerjaannya sesuai dengan SOP dan alur yang diberikan.

\section{Variabel Yang Paling Berpengaruh Terhadap Kinerja Karyawan}

Dari tiga variabel independen atau bebas yang diteliti, variabel Dukungan Organisasi memiliki pengaruh paling signifikan dengan nilai beta standar 0,345 dimana nilai ini lebih besar dibandingkan dengan variabel Motivasi Kerja dan Manajemen Pengetahuan. Sehingga dapat diambil kesimpulan bahwa Dukungan Organisasi yang paling berpengaruh terhadap Kinerja Karyawan di Hotel Chanti Semarang.

\section{H. SIMPULAN}

Ada pengaruh positif dan signifikan variabel Motivasi Kerja terhadap Kinerja Karyawan di Hotel Chanti Semarang, sehingga hipotesis pertama diterima. Ada pengaruh positif dan signifikan variabel Manajemen Pengetahuan terhadap Kinerja Karyawan di Hotel Chanti Semarang, sehingga hipotesis kedua diterima. Ada pengaruh positif dan signifikan variabel Dukungan Organisasi terhadap Kinerja Karyawan di Hotel Chanti Semarang, sehingga hipotesis ketiga diterima. Ada pengaruh positif dan signifikan variabel Motivasi Kerja, Manajemen Pengetahuan, dan Dukungan Organisasi terhadap Kinerja Karyawan di Hotel Chanti Semarang, sehingga hipotesis keempat diterima.

Variabel Dukungan Organisasi lebih berpengaruh dibanding variabel Motivasi Kerja dan Manajemen Pengetahuan terhadap Kinerja Karyawan di Hotel Chanti Semarang, sehingga hipotesis kelima dapat diterima.

\section{Daftar Referensi}


Abdurrohman, S. 2021. (n.d.). Pengaruh budaya organisasi terhadap efektivitas manajemen pengetahuan di disperkim pemprov jabar. 2 .

Abor, J., \& Bokpin, G. A. (2010). Investment opportunities, corporate finance, and dividend payout policy. Studies in Economics and Finance, 27(3), 180-194. https://doi.org/10.1108/10867371011060018

Aizid, R. (2016). Biografi Ulama Nusantara. Diva Press.

Anwar, R., Darmawan, D., \& Setiawan, C. (2016). Kajian Kitab Tafsir dalam Jaringan Pesantren di Jawa Barat. Wawasan: Jurnal Ilmiah Agama Dan Sosial Budaya, 1(1), 56-69. https://doi.org/10.15575/jw.v1i1.578

Arifandi, M., \& Presilawati, S.E., M.M, F. (2020). Pengaruh Personal Knowledge,Job Procedure Dan Technology Terhadap Kinerja Pegawai Pada Dinas Sosial Aceh. Jurnal Ilmiah Manajemen Muhammadiyah Aceh, 9(2), 133-168. https://doi.org/10.37598/jimma.v9i2.814

Cretu, A. E., \& Brodie, R. J. (2007). The influence of brand image and company reputation where manufacturers market to small firms: A customer value perspective. Industrial Marketing Management, 36(2), 230-240. https://doi.org/10.1016/j.indmarman.2005.08.013

Dana, N., \& Dewi, A. (2016). Pengaruh Kompensasi Dan Dukungan Organisasi Terhadap Kinerja Karyawan Di Hotel Asana Agung Putra Bali. None, 5(9), 254211.

Ekobelawati, F. (2001). PENGARUH KNOWLEDGE MANAGEMENT TERHADAP KINERJA KARYAWAN Fransiska Ekobelawati Akademi Sekretari Manajemen Indonesia Pontianak ( ASMI) Email: Sischasira06@Gmail.com.20-24.

Erawati, A. H. (2015). Pengaruh Lingkungan Kerja dan Motivasi Kerja terhadap Kinerja Karyawan di Hotel Aamaris Makassar. Jurnal Economix, 3(1), 82-93.

Fata, R. (2020). Pengaruh Dukungan Organisasi dan Kontrol Diri Terhadap Disiplin. Jurnal Psikologi, 16(2), 28-36.

Hadi, S. P., Bisnis, D. A., \& Diponegoro, U. (2019). PENGARUH MOTIVASI KERJA DAN PERSONAL KNOWLEDGE TERHADAP KINERJA KARYAWAN Pendahuluan Kerangka Teori. IX(Iv), 482-487.

Harianto, A. (2016). Pengaruh Motivasi Kerja Terhadap Komitmen Afektif Dengan Kepuasan Kerja Sebagai Variabel Mediator Di Hotel X. Kinerja, 20(2), 95. https://doi.org/10.24002/kinerja.v20i2.837

Hasyim, M. A. N., Maje, G. I. L., Alimah, V. ', \& Priyadi, S. A. P. (2020). Pengaruh Motivasi dan Disiplin Kerja Terhadap Kinerja Karyawan PT.Kahatex. Jesya (Jurnal Ekonomi \& Ekonomi Syariah), 3(2), 58-69. https://doi.org/10.36778/jesya.v3i2.161

Hayati, N. (2020). Pengaruh Persepsi Dukungan Organisasi Dan. Equilibrium: Jurnal Ekonomi Manajemen-Akuntansi, 16(2), 54-61.

Ihsan, M., Sari, V. N., \& Putra, R. A. (2021). Karyawan Dengan Gaya Kepemimpinan Sebagai Variabel Moderating Pada PT P\&P Lembahkaret. 4(2), 190-203.

Indarjanti, P., \& Bodroastuti, T. R. I. (2012). Pengaruh Kemampuan, Usaha Dan Dukungan Organisasi Terhadap Kinerja The Influence of Ability, Effort and Support of Organization to Employee's Performance. Kajian Akuntansi Dan Bisnis, 64-83. https://www.neliti.com/publications/102597/pengaruh-kemampuan-usaha-dandukungan-organisasi-terhadap-kinerja

Iskandar, A., \& Subekan, A. (2018). the Pengaruh Personal Knowledge, Job Procedure Dan Technology Terhadap Kinerja Pegawai Organisasi Publik. JRMSI - Jurnal Riset Manajemen Sains Indonesia, 9(2), 168-192. https://doi.org/10.21009/jrmsi.009.2.01

Jauvani, E. (2017). Pengaruh Stres Kerja Terhadap Kinerja Karyawan: Studi Kasus pada Tenaga. $4(1), 221-228$.

Jensen, M. C., \& Meckling, W. H. (1976). Theory of the firm: Managerial behavior, agency costs and ownership structure. Journal of Financial Economics, 3(4), 305-360. https://doi.org/10.1016/0304-405X(76)90026-X

Kandou, yunita lidya. (2016). PENGARUH KNOWLEDGE MANAGEMENT, SKILL DAN ATTITUDE TERHADAP KINERJA KARYAWAN ( STUDI PADA PT . BANK SULUTGO KANTOR PUSAT DI MANADO ). 16(01), 147-158.

Kartika, E. W., Kaihatu, T. S., Perhotelan, P. M., Ekonomi, F., \& Petra, U. K. (2010). Analisis Pengaruh Motivasi Kerja Terhadap Kepuasan Kerja (Studi Kasus pada Karyawan Restoran di Pakuwon 
Food Festival Surabaya). Jurnal Manajemen Dan Kewirausahaan (Journal of Management and Entrepreneurship), 12(1), 100-112. https://doi.org/10.9744/jmk.12.1.pp.100-112

Mahendra, I. (2015). Analisa Penerimaan Pengguna Sistem Inforasi Koperasi Pada Koperasi Karyawan Budi Setia Jakarta Dengan Technologi Acceptance Model. Jurnal Pilar Nusa Mandiri, $X I(1), 70-80$.

Miskiani, K. A., \& Bagia, I. W. (2021). Peningkatan Kinerja Karyawan Melalui Motivasi Kerja. 2(2), 120-129.

Mujiasih, E. (2015). Hubungan Antara Persepsi Dukungan Organisasi (Perceived Organizational Support) Dengan Keterikatan Karyawan. Jurnal Psikologi Undip, 14(1), 40-51. https://doi.org/10.14710/jpu.14.1.40-51

Muliharta, K. (2015). Pengaruh Kemampuan kerja dan motivasi kerja terhadap kinerja karyawan pada hotel Puri Bugis LovinaMuliharta, Ketut. Jurnal Jurusan Pendidikan Ekonomi (JIPE), 5(1), $1-14$.

Nugrahanto, A. D. (2015). Blusukan Dalam Sejarah : Dari Sambernyawa sampai Jokowi. Kompasiana.

Nugroho, A., Tanoyo, K., \& Yudha w., T. (2013). Pengaruh Lingkungan Kerja Terhadap Kinerja Karyawan Hotel Majapahit Surabaya. Journal of Chemical Information and Modeling, 53(9), 1689-1699.

Oktavian, A., Prasetia, A., Masnun, M., \& Widoro, W. (2021). Pengaruh Pelatihan dan Berbagi Pengetahuan Terhadap Kinerja Karyawan Melalui Pengetahuan Manajemen. MASTER: Jurnal Manajemen Strategik Kewirausahaan, 1(1), 69-78. https://doi.org/10.37366/master.v1i1.132

Pamulang, U. (2021). Konsepsi motivasi kerja dalam upaya meningkatkan kinerja karyawan. 4(1), $11-20$.

Putra, G. (2013). Pengaruh Disiplin Kerja, Gaya Kepemimpinan, Dan Motivasi Kerja Terhadap Kinerja Karyawan Pada Hotel Matahari Terbit Bali, Tanjung Benoa-Nusa Dua. E-Jurnal Manajemen Universitas Udayana, 2(7), 253493.

Rahmawati, R., Yahiji, K., \& Rusli, M. (2019). Mopo'alati Tradition In The Coastal Muslim Community At Molotabu Beach Bone Bolango District. Wawasan: Jurnal Ilmiah Agama Dan Sosial Budaya, 4(1), 65-79. https://doi.org/10.15575/jw.v4i1.4080

Retnoningsih, E. (2013). Knowledge Management System (KMS) Dalam Meningkatkan Inovasi LPPM Perguruan Tinggi. Evolusi, I(1), 76-85.

Ross, S. A. (1977). The Determination of Financial Structure: The Incentive-Signalling Approach. The Bell Journal of Economics, 8(1), 23. https://doi.org/10.2307/3003485

Rozalia, N. (2015). PENGARUH MOTIVASI KERJA DAN DISIPLIN KERJA TERHADAP KINERJA KARYAWAN (Studi Kasus Pada Karyawan PT. Pattindo Malang). Jurnal Administrasi Bisnis S1 Universitas Brawijaya, 26(2), 86280.

Susmiati. (2015). Pengaruh Budaya Organisasi Dan Dukungan Organisasi Persepsian Terhadap Kinerja Karyawan Dengan Komitmen Organisasi Sebagai Variabel Intervening. Management Analysis Journal, 4(1), 79-87. https://doi.org/10.15294/maj.v4i1.7226

Tina Febriani, N., \& Desi Indrawati, A. (2013). Pengaruh Motivasi, Kompensasi, Serta Lingkungan Kerja Fisik Terhadap Kinerja Kerja Karyawan Hotel the Niche Bali. E-Jurnal Manajemen Universitas Udayana, 2(5), 254973.

Wijayanti, D. P., \& Sundiman, D. (2017). Pengaruh Knowledge Management Terhadap Kinerja Karyawan (Studi Empiris Pada Pt. Sms Kabupaten Kotawaringin Timur). DeReMa Jurnal Manajemen, 12(1), 69-85.

Zarkowi, R., \& Widiartanto. (2016). Pengaruh Personal Knowledge, Organizational Learning, Dan Teknologi Terhadap Kinerja Karyawan Hotel Patra Jasa Semarang. National Conference on ASBIS 2016, 1(1), 294-302. 
Peluang dan Tantangan Pengembangan Souvenir Desa Wisata Berbasis Kerajinan Lokal Gusti Ngurah Adi Wiriatama, Nyoman Dini Andiani

Halaman ini sengaja dikosongkan

98 Masyarakat Pariwisata: Journal of Community Services in Tourism, Volume 2 Nomor 2, 2021: 75-98 